\title{
Impact of Different Tillage Methods on Silty Loam Luvisol Water Content in Sugar Beet (Beta vulgaris L.) Crop
}

\author{
Kęstutis Romaneckas ${ }^{1}$, Egidijus Šarauskis ${ }^{2}$, Laura Masilionytė ${ }^{2,3}$, Antanas Sakalauskas ${ }^{2}$, \\ Vytautas Pilipavičius ${ }^{1}$ \\ ${ }^{1}$ Institute of Agroecosystems and Soil Sciences, Aleksandras Stulginskis University, Kaunas, Lithuania; ${ }^{2}$ Institute of Agricultural and \\ Safety Engineering, Aleksandras Stulginskis University, Kaunas, Lithuania; ${ }^{3}$ Joniškèlis Experimental Station, Lithuanian Research \\ Centre of Agriculture and Forestry, Joniškèlis, Lithuania. \\ Email: kestas.romaneckas@asu.lt, egidijus.sarauskis@asu.lt, laura.masilionyte@gmail.com, antanas.sakalauskas@asu.lt, \\ vytautas.pilipavicius@asu.lt
}

Received December $15^{\text {th }}, 2012$; revised January $14^{\text {th }}, 2013$; accepted February $10^{\text {th }}, 2013$

\begin{abstract}
The regulation of water regime in the soil is the most important task in semi-humid climate with not even precipitation distribution conditions. Reduced or minimum tillage may change soil hydrological properties. The objectives of this study were to investigate the possibilities to manage soil water regime during the whole soil tillage system for sugar beet, which are especially sensitive for water deficit or abundance. Five field experiments were carried out at the Experimental Station of the Lithuanian University of Agriculture (Aleksandras Stulginskis University since 2011) $\left(54^{\circ} 52^{\prime} \mathrm{N}, 23^{\circ} 49^{\prime} \mathrm{E}\right)$ during $1995-2010$. The soil of the experiments was silty loam Luvisol. In this study we highlighted the reduction of primary soil tillage from deep annual soil ploughing to shallow ploughing, deep and shallow cultivation and no till, comparison of soil ploughing and subsoiling, presowing ploughed or unploughed soil tillage with different cultivators-S-tine, complex, rotary and others, soil compressing with Cambridge and spur rollers before and after sugar beet sowing investigations. According to the results of experiments, reduction of primary soil tillage conserved soil water. The highest storage of soil water in spring was observed in non-reversibly tilled or not tilled soil. Subsoiling led higher water infiltration rate, and top layer of subsoiled soil consisted less moisture content than ploughed. Sugar beet seedbed moisture mostly depended on soil tillage intensity and depth. Presowing rotary tilling was the top tillage method in the case of water preservation in ploughed or unploughed soil. Soil compressing with rollers mostly had negative or low influence on light loam Luvisol moisture content. Rolling with Cambridge roller effected on more rapid water transport from deeper to top sugar beet seedbed layers and higher evaporation rate.
\end{abstract}

Keywords: Soil Tillage Methods; Soil Moisture; Sugar Beet Crop

\section{Introduction}

Soil moisture content depends on precipitation rate, air temperature, and relief, depth of ground water, soil type, humus content, water infiltration rate and grown plants $[1$, 2]. Moisture regime (especially deficit) limits the formation of plant productivity, reduces the possibility of realizing the cumulated bio-potential, which cannot be compensated in later plant growth stages. Therefore, soil water resource optimization in order to increase its efficiency in reducing environmental degradation processes, is one of the most important objectives in agriculture [3-5].

Soil tillage may influence on soil properties, especially on soil water content [6]. There was established strong relation between soil tillage, soil compaction, bulk density, aeration and water permeability. Reduced soil tillage increased soil bulk density and compaction and reduced soil aeration and water permeability [7-9]. On the other hand, minimum tillage improves soil structure, and crop residues better conserve soil moisture [10] and it is more efficient to use in comparison with intensive tillage. In spring time minimally tilled soil frequently consists higher amount of water than intensively tilled. In Lithuanian semi-humid climate conditions intensive soil tillage increased topsoil moisture release into the environment [11]. Other authors' studies showed that, for example, direct seeding in wet years leads lower and in dry-higher soil moisture content. In no ploughed soil moisture content of the upper layers increased, but it decreased in the deeper layers as compared to conventional tillage [12]. In Moraru et al. [13] experiment moisture determinations showed significant differences, statistically insured, at no-till (wheat $76 \%$; soya-bean $86 \%$ ), although high va- 
lues were recorded at minimum tillage, too. Soil moisture was higher in NT and MT at the time of sowing and at the early stages of vegetation, then the differences diminished over time. Water dynamics did not show differences that could affect crop yields.

The influence of soil tillage intensity on soil water content are well documented, however, there is no complex evaluation of the whole tillage system for sugar beet, which consist of primary tillage, subsoiling, presowing tillage of different intensity and tillage after sowing. So, the aim of our article is to review and highlight the possibilities to manage soil water regime in all steps of soil tillage system for sugar beet.

\section{Materials and Methods}

\subsection{Site and Soil Description}

Five field experiments were carried out at the Experimental Station of the Lithuanian University of Agriculture (Aleksandras Stulginskis University since 2011) $\left(54^{\circ} 52^{\prime} \mathrm{N}, 23^{\circ} 49^{\prime} \mathrm{E}\right)$ [14] during 1995-2010. The soil of the experimental sites was clay loam over moraine clay on a silty loam (Calc(ar)i-Epihypogleyic Luvisol, LVg-p$w-c c(s c)$ ) [15]. Soil chemical properties are presented in Table 1.

\subsection{Experimental Design and Agricultural Practice}

The number of replications per each experiment was four, plot distribution was randomized. The space between the rows of sugar beets was $0.45 \mathrm{~m}$, the distance between seeds $0.11-0.16 \mathrm{~cm}$. Pre-crops of sugar beet were winter wheat, winter triticale and spring barley. Agricultural practice of experiments is presented in Table 2.

\subsection{Weather Conditions}

The Lithuanian climate lies between maritime and continental, with wet winters and moderate summers. Winter temperatures are usually below freezing. Rainfall is distributed throughout the year, but more rain tends to fall on the coast of the Baltic Sea. Summer is the wettest season. The average annual precipitation is 720 millimeters on the coast and 490 millimeters in the eastern part of the country.

Lithuanian climate is uneven. The variation of precipitation mostly is up to $45 \%-50 \%$ or more. So, the influence of soil tillage on soil moisture content is not clearly expressed year by year. Different soil tillage methods had stronger influence on soil top layer water content in dry weather conditions. The variation of rainfall during experiments execution is presented in Table 3.

In Lithuania sowing of summer plants starts at the end of April. In this period the trend of rainfall rate shows
Table 1. Soil chemical properties.

\begin{tabular}{lcc}
\hline Index & Amount of elements & Evaluation \\
\hline $\mathrm{pH}$ & $6.9-7.1$ & Neutral \\
Humus $\mathrm{g} \cdot \mathrm{kg}^{-1}$ & $2.1-2.7$ & Average \\
$\mathrm{P}_{2} \mathrm{O}_{5} \mathrm{mg} \cdot \mathrm{kg}^{-1}$ & $100-250$ & Sufficient $/ \mathrm{high}$ \\
$\mathrm{K} 2 \mathrm{O} \mathrm{mg} \cdot \mathrm{kg}^{-1}$ & $70-170$ & Low/sufficient \\
$\mathrm{Ca} \mathrm{mg} \cdot \mathrm{kg}^{-1}$ & $2100-3600$ & Very high \\
\hline
\end{tabular}

decrease of precipitation (Figure 1), which negatively influenced on seed germination of agricultural plants. So, the qualitative tillage and possibility to conserve moisture in the soil become a very important task.

\subsection{Experimental Methods}

Gravimetric water content (mass wetness) [16] was determined by the cylindrical and weighing methods. Cylinder size was $200 \mathrm{~cm}^{3}$. Sampling depth-from 10 to 40 $\mathrm{cm}$. Soil samples were taken in 4 places per each plot. Sugar beet seedbed moisture content was determined by Kritz method $[17,18]$. Experimental data were analyzed by Anova. The treatment effects were tested by P test.

Each year data were analyzed separately. The trial data were also evaluated using correlation and regression analysis by Sigma Plot 8.0 software.

\section{Results and Discussion}

\subsection{Primary Soil Tillage}

Stationary long-term field experiment was performed during 2001-2005. Five types of soil tillage methods were compared-from conventional deep mould-board ploughing to deep or shallow cultivation and no tillage. Different soil tillage was performed in autumn time before wintering. Stubble disking was made 2 weeks before primary soil tillage (except no tillage plots).

In conditions of ploughless soil tillage or no-till more plant residues are left on or near the soil surface, which led to lower evapotranspiration and higher content of soil water [19-21]. Marginally cultivated soils in spring contain more moisture than in the case of intensive tillage [22-24].

Similarly in our experiment reduction of primary soil tillage intensity increased the amount of moisture in the soil upper layer $(0-10 \mathrm{~cm})$ (Table 4).

According to the average data of 2001-2005, the highest amount of moisture was observed in no tilled soil (NT) before pre-sowing soil tillage $(25.8 \%)$ and after sowing till sugar beet germination $(22.9 \%)$. Soil tillage intensity had no significant influence on moisture content in a deeper $(10-20 \mathrm{~cm})$ soil. 
Table 2. The agricultural practice of sugar beet growing in field experiments.

\begin{tabular}{|c|c|c|c|c|c|}
\hline Title of experiment & $\begin{array}{l}\text { Execution } \\
\text { years }\end{array}$ & $\begin{array}{c}\text { Status of } \\
\text { experiment }\end{array}$ & Tillage treatments & $\begin{array}{l}\text { Initial size } \\
\text { of plot } \mathrm{m}^{2}\end{array}$ & $\begin{array}{l}\text { Fertilization } \\
\text { rate }\end{array}$ \\
\hline $\begin{array}{l}\text { I. The reduction of } \\
\text { primary soil tillage } \\
\text { intensity for sugar beet }\end{array}$ & $2001-2005$ & $\begin{array}{l}\text { Long-term, } \\
\text { stationary }\end{array}$ & $\begin{array}{l}\text { 1. Conventional ploughing with moldboard plough up to } 22-25 \\
\text { cm depth; } \\
\text { 2. Shallow ploughing with moldboard plough up to } 12-15 \\
\text { cm depth; } \\
\text { 3. Deep cultivation with chisel cultivator up to } 25-30 \mathrm{~cm} \text {; } \\
\text { 4. Shallow cultivation with disc cultivator up to } 12-15 \mathrm{~cm} \text { depth; } \\
\text { 5. No tilled. }\end{array}$ & 84.0 & $\begin{array}{c}\mathrm{N}_{60+60} \\
\mathrm{P}_{80} \\
\mathrm{~K}_{160}\end{array}$ \\
\hline $\begin{array}{l}\text { II. The investigations } \\
\text { of presowing soil } \\
\text { tillage methods for } \\
\text { sugar beet in ploughed } \\
\text { soil }\end{array}$ & 1995-1999 & Short-term & $\begin{array}{l}\text { 1. Deep extensive (with S-tine cultivator up to } 5-6 \mathrm{~cm} \text { depth); } \\
\text { 2. Shallow intensive (with complex cultivator RAU Ecomat up to } \\
3 \text { - } 4 \mathrm{~cm} \text { depth); } \\
\text { 3. Shallow with rotors (with rotary tiller up to } 3-4 \mathrm{~cm} \text { depth). }\end{array}$ & 26.5 & $\begin{array}{c}\mathrm{N}_{120} \\
\mathrm{P}_{80} \\
\mathrm{~K}_{160} \\
\mathrm{~B}_{0.9}\end{array}$ \\
\hline $\begin{array}{l}\text { III. The minimization } \\
\text { of presowing tillage } \\
\text { methods for sugar beet } \\
\text { in unploughed soil } \\
\text { (stubble cultivation) }\end{array}$ & $2000-2002$ & Short-term & $\begin{array}{l}\text { 1. No tilled straw; } \\
\text { 2. Intensive straw tillage with rotary tiller up to } 3-4 \mathrm{~cm} \text { depth; } \\
\text { 3. Intensive straw tillage with rotovator up to } 3-4 \mathrm{~cm} \text { depth; } \\
\text { 4. Conventional technology (ploughing with moldboard plough in } \\
\text { autumn, presowing soil tillage with S-tine cultivator twice up to } \\
4-5 \mathrm{~cm} \text { depth). }\end{array}$ & 36.0 & $\begin{array}{c}\mathrm{N}_{55+60} \\
\mathrm{P}_{85} \\
\mathrm{~K}_{150} \\
\mathrm{~B}_{0.9}\end{array}$ \\
\hline $\begin{array}{l}\text { IV. Effect of seedbed } \\
\text { compressing for sugar } \\
\text { beet }\end{array}$ & $\begin{array}{l}1998-1999 \\
2002 \\
2004-2005 \\
2007\end{array}$ & Long-term & $\begin{array}{l}\text { 1. No compressed; } \\
\text { 2. Compressed with Cambridge roller before sowing; } \\
\text { 3. Compressed with spur roller before sowing; } \\
\text { 4. Compressed with Cambridge roller after sowing; } \\
\text { 5. Compressed with spur roller after sowing. }\end{array}$ & $12.0-16.0$ & $\begin{array}{c}\mathrm{N}_{50+60} \\
\mathrm{P}_{59} \\
\mathrm{~K}_{135}\end{array}$ \\
\hline $\begin{array}{l}\text { V. Subsoiling for sugar } \\
\text { beet }\end{array}$ & $2009-2010$ & $\begin{array}{l}\text { Short-term, } \\
\text { on-farm scale }\end{array}$ & $\begin{array}{l}\text { 1. Conventional ploughing with moldboard plough up to } 20-22 \\
\mathrm{~cm} \text { depth; } \\
\text { 2. Deep soil tillage with subsoiler (Agrisem Combiplow) up to } \\
40-45 \mathrm{~cm} \text { depth. }\end{array}$ & 50,000 & $\begin{array}{c}\mathrm{N}_{48+68} \\
\mathrm{P}_{78} \\
\mathrm{~K}_{135}\end{array}$ \\
\hline
\end{tabular}

Table 3. The rainfall during sugar beet growing seasons. Kaunas meteorological station.

\begin{tabular}{|c|c|c|c|c|c|c|c|}
\hline Year/Month & April & May & June & July & August & September & October \\
\hline 1995 & 42.1 & 78.4 & 76.9 & 47.0 & 47.7 & 75.1 & 18.0 \\
\hline 1996 & 24.8 & 70.6 & 64.0 & 88.9 & 17.4 & 33.5 & 43.5 \\
\hline 1997 & 45.4 & 65.1 & 75.2 & 62.9 & 45.0 & 65.6 & 69.7 \\
\hline 1998 & 64.9 & 36.2 & 59.5 & 118.0 & 84.1 & 21.8 & 54.4 \\
\hline 1999 & 42.0 & 32.4 & 53.9 & 30.5 & 85.9 & 28.7 & 79.4 \\
\hline 2000 & 4.2 & 41.8 & 64.4 & 113.0 & 53.5 & 15.0 & 4.2 \\
\hline 2001 & 32.2 & 58.4 & 45.7 & 144.5 & 55.0 & 75.3 & 77.3 \\
\hline 2002 & 28.1 & 30.4 & 93.1 & 53.5 & 13.8 & 42.3 & 167.0 \\
\hline 2003 & 32.3 & 45.1 & 57.1 & 118.2 & 53.4 & 27.9 & 89.5 \\
\hline 2004 & 15.1 & 38.3 & 62.9 & 78.5 & 98.0 & 35.3 & 80.7 \\
\hline 2005 & 37.4 & 76.9 & 78.1 & 45.4 & 136.2 & 46.5 & 10.8 \\
\hline 2006 & 29.3 & 74.5 & 18.0 & 70.7 & 165.6 & 89.8 & 47.7 \\
\hline 2007 & 22.2 & 96.5 & 70.0 & 148.7 & 78.6 & 41.5 & 56.7 \\
\hline 2008 & 32.1 & 35.5 & 83.2 & 43.0 & 99.3 & 27.0 & 69.8 \\
\hline 2009 & 8.6 & 42.0 & 107.4 & 83.8 & 87.5 & 28.3 & 101.2 \\
\hline 2010 & 58.5 & 94.8 & 127.0 & 100.7 & 82.3 & 63.3 & 44.6 \\
\hline $1974-2010$ & 38.1 & 47.2 & 66.7 & 83.0 & 73.2 & 53.8 & 54.8 \\
\hline
\end{tabular}


Table 4. The influence of primary tillage methods on moisture content in top soil layers, 2001-2005.

\begin{tabular}{cccc}
\hline $\begin{array}{c}\text { Soil tillage } \\
\text { methods }\end{array}$ & $\begin{array}{c}\text { Sampling } \\
\text { depth cm }\end{array}$ & $\begin{array}{c}\text { Before soil } \\
\text { tillage in spring \% }\end{array}$ & $\begin{array}{c}\text { Till sugar beet } \\
\text { germination \% }\end{array}$ \\
\hline CP & $0-10$ & 22.8 & 20.6 \\
& $10-20$ & 24.7 & 22.6 \\
SP & $0-10$ & 22.6 & 19.8 \\
& $10-20$ & 25.6 & 21.4 \\
DC & $0-10$ & 24.9 & $22.2^{*}$ \\
& $10-20$ & 24.9 & 22.7 \\
SC & $0-10$ & 24.1 & $22.1^{*}$ \\
& $10-20$ & 26.3 & 21.2 \\
NT & $0-10$ & $25.8^{*}$ & $22.9^{*}$ \\
& $10-20$ & 23.8 & 21.9 \\
\hline
\end{tabular}

$\mathrm{CP}=$ conventional ploughing with mould-board plough up to $22-25 \mathrm{~cm}$ depth; $\mathrm{SP}=$ shallow ploughing with mould-board plough up to $12-15 \mathrm{~cm}$ depth; $\mathrm{DC}=$ deep cultivation with chisel cultivator up to $25-30 \mathrm{~cm} ; \mathrm{SC}=$ shallow cultivation with disc cultivator up to $12-15 \mathrm{~cm}$ depth; NT $=$ no tilled; * significant difference from control treatment $(\mathrm{CP})$ at $\mathrm{P} \leq 0.05$.

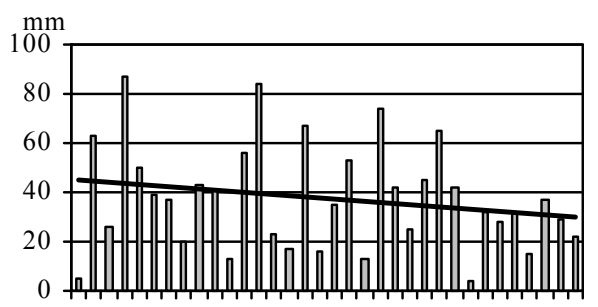

Figure 1. The trend of rainfall in April. Kaunas meteorological station, 1974-2007. $\bar{x}=37.3 ; \mathrm{Mo}=36.7 ; \mathrm{V} \%=$ 56.4 .

\subsection{Subsoiling}

Subsoiling is the process of deep tilling of the ground (up to $40-50 \mathrm{~cm}$ depth). It is mainly used to uncompact the soil, but also improves aeration of the soil, water infiltration, soil water capacity and dispersion of nutrients.

Conventional mould-board ploughing was compared with subsoiling in on-farm scale experiment. Soil tillage was performed in autumn time before wintering. Soil water content was measured three times: after subsoiling in autumn 2009, before pre-sowing soil tillage in spring 2010 and before sugar beet harvesting in autumn 2010 . Investigation data showed, that mean water content in top $0-5 \mathrm{~cm}$ depth soil layer was higher in ploughed soil $(25.8 \%)$, than in subsoiled $(23.3 \%)$ because of slower water infiltration. Such conditions influenced on disappearance of some sugar beet plants, especially in the wettest places.

Deep subsoiling leads to $4 \mathrm{t} \cdot \mathrm{ha}^{-1}$ higher sugar beet root production and by $0.86 \%$ unit higher sucrose content in comparison with ploughed one.

\subsection{Pre-Sowing Tillage of Ploughed Soil}

Short-term field experiment was carried out during 19951998. In autumn ploughed soil before sowing was cultivated with three different cultivators: S-tine (deep extensive pre-sowing tillage), complex (shallow intensive tillage) and rotary. According to the data of experiment, pre-sowing soil tillage up to $5-6 \mathrm{~cm}$ depth influenced on faster water evaporation from the top layers of the soil (Table 5). In shallowly tilled soil water content was sig-

Table 5. Impact of ploughed soil presowing tillage methods on soil moisture content.

\begin{tabular}{|c|c|c|c|c|c|c|c|c|c|}
\hline \multirow{2}{*}{ Soil tillage method } & \multirow{2}{*}{$\begin{array}{l}\text { Sampling depth } \\
\mathrm{cm}\end{array}$} & \multicolumn{2}{|c|}{1995} & \multicolumn{2}{|c|}{1996} & \multicolumn{2}{|c|}{1997} & \multicolumn{2}{|c|}{1998} \\
\hline & & $A$ & $V$ & $A$ & $V$ & $A$ & $V$ & $A$ & $V$ \\
\hline \multirow{4}{*}{ Deep extensive } & $0-10$ & 19.3 & 15.1 & 19.4 & 15.7 & 22.7 & 16.9 & 24.1 & 19.8 \\
\hline & $10-20$ & 23.8 & 16.8 & 22.1 & 15.9 & 25.2 & 17.9 & 23.6 & 20.6 \\
\hline & $20-30$ & - & 15.5 & - & 16.0 & - & 17.4 & - & 20.7 \\
\hline & $30-40$ & - & 14.9 & - & 16.2 & - & 12.6 & - & 18.5 \\
\hline \multirow{4}{*}{ Shallow intensive } & $0-10$ & $22.0^{*}$ & 14.9 & 19.9 & 16.4 & $24.7^{*}$ & $18.4^{*}$ & 22.5 & 20.3 \\
\hline & $10-20$ & 22.9 & 16.4 & 22.9 & 16.7 & 26.7 & 19.3 & $25.4^{*}$ & 19.2 \\
\hline & $20-30$ & - & 15.5 & - & 16.9 & - & 18.7 & - & 19.5 \\
\hline & $30-40$ & - & 13.7 & - & 17.1 & - & $14.4^{*}$ & - & 17.9 \\
\hline \multirow{3}{*}{ Shallow with rotors } & $10-20$ & 24.4 & 17.0 & 22.0 & $17.9^{*}$ & 26.0 & 18.7 & $26.1^{*}$ & 19.4 \\
\hline & $20-30$ & - & 16.0 & - & $18.0^{*}$ & - & 18.6 & - & 19.5 \\
\hline & $30-40$ & - & 15.2 & - & $18.3^{*}$ & - & $15.0^{*}$ & - & 18.6 \\
\hline
\end{tabular}

$\mathrm{A}=$ soil moisture content $\%$ after sowing during sugar beet germination; $\mathrm{V}=$ continuously during sugar beet vegetation. Precipitation rate during sugar beet vegetation in 1995 - $303.9 \mathrm{~mm}, 1996$ - $250.4 \mathrm{~mm}, 1997$ - $339.9 \mathrm{~mm}, 1998$ - $338.6 \mathrm{~mm}$. ${ }^{*}$ significant difference from control treatment (deep extensive soil tillage) at $\mathrm{P} \leq 0.05$. 
nificantly higher. However, this effect mostly was short and depended on precipitation rate.

Higher differences were observed in dry conditions of 1996. Pre-sowing soil tillage with rotary tiller influenced on higher water content from top to deeper (up to $30-40$ $\mathrm{cm})$ soil layers.

\subsection{Pre-Sowing Tillage of Stubble}

Short-term field experiment was performed during 20002002. The main task of experiment was to compare different soil tillage methods for stubble cultivation and its influence on sugar beet seedbed moisture content. The comparable control treatment was conventional for Lithuanian technology_deep ploughing in autumn, Stine cultivation before sowing twice.

The data of experiment showed that stubble tillage with rotary tiller and no tillage (direct sowing) led to significantly higher amount of water in different sugar beet seedbed layers (Table 6). Stubble cultivation with rotovator increased seedbed water content but significantly - in deeper layer only.

Sugar beet seedbed moisture content depended on depth of tillage (Figure 2).

\subsection{Soil Compressing}

Long-term field experiment was carried out in 1998, 1999 and 2002 and with modified methodology_in 2004, 2005 and 2007. Before and shortly after sowing the soil was pressed with a complex roller KKN-2.8 (Cambridge roller). The working width of the roller was $2.8 \mathrm{~m}$, mass per meter of working width-256.4 kg. In other plots the soil was pressed with a spur roller $3 \mathrm{KKS}$-6, working width- $6.0 \mathrm{~m}$ (only one section of the three was used; working width $2.0 \mathrm{~m}$ ) and mass per meter of working width $300.8 \mathrm{~kg}$ [25].

Soil compressing (rolling) is especially useful in dry spring, while in the dry soil layer sugar beet seeds need more time to swell and their germination is uneven. Compressing improves the consolidation of soil aggre-

Table 6. Impact of reduced primary soil tillage on sugar beet seedbed moisture content till sugar beet germination, 2000-2002.

\begin{tabular}{lccc}
\hline Soil tillage methods & \multicolumn{3}{c}{ Sugar beet seedbed layers } \\
\cline { 2 - 4 } & $0-1.5 \mathrm{~cm}$ & $1.5-3.0 \mathrm{~cm}$ & $3.0-4.5 \mathrm{~cm}$ \\
\hline $\begin{array}{l}\text { Conventional tillage } \\
\text { Stubble tillage with rotary tiller }\end{array}$ & 16.3 & 14.3 & 6.5 \\
$\begin{array}{l}\text { up to 3 - 4 cm depth } \\
\text { Stubble tillage with rotovator }\end{array}$ & $18.7^{*}$ & $17.9^{*}$ & $12.5^{*}$ \\
$\begin{array}{l}\text { up to 3 - 4 cm depth } \\
\text { No tilled stubble }\end{array}$ & $20.1^{*}$ & 17.1 & $10.4^{* *}$ \\
\hline
\end{tabular}

* significant difference from control treatment (conventional tillage) at $\mathrm{P} \leq$ $0.05 ;^{* *}$ - at $\mathrm{P} \leq 0.01$.

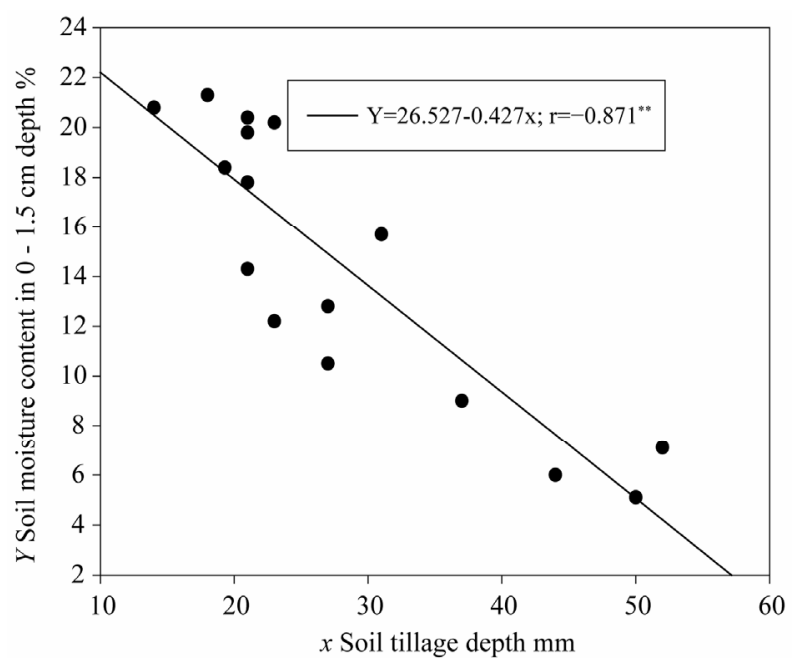

(a)

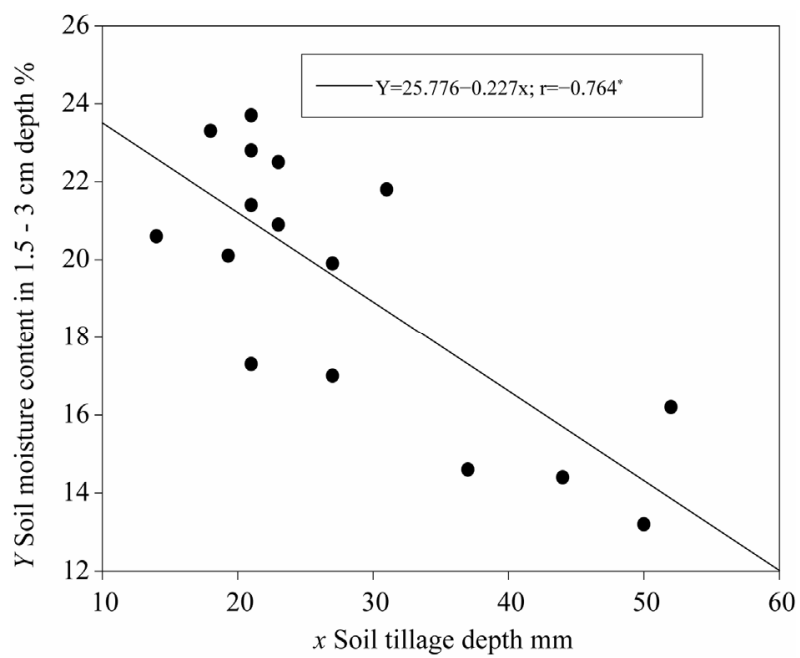

(b)

Figure 2. Relation between pre-sowing tillage depth and soil moisture content in sugar beet seedbed.

gates and seeds, increases capillary moisture movement which is necessary for sugar beet seed germination $(18 \%$ - 22\%) $[18,26]$. In the lightest and heaviest soils compressing reduces evaporative water losses. Conversely, compressing increases water loses in the intermediate textured soils [18]. Similarly, in our primary experiment soil compressing mostly had negative or low influence on light loam soil moisture content (Table 7). Only applying of heavy spur roller before sugar beet sowing led to some tendencies of water content increase.

However, in our other investigations sugar beet seedbed moisture content in upper seedbed layer was higher after its compressing with Cambridge roller before and after sowing (Table 8). That influence on rapid soil water and sugar beet yield (data are not presented) loss. Seedbed compressing mostly had negative, but not significant effect on moisture content in deeper (1.5 - 3.0 and $3.0-4.5 \mathrm{~cm}$ depth) seedbed layers. Only seedbed 
Table 7. The influence of soil compressing methods and time on soil moisture content till sugar beet germination, 1998-1999, 2002.

\begin{tabular}{lcc}
\hline \multirow{2}{*}{$\begin{array}{l}\text { Soil compressing method } \\
\text { and time }\end{array}$} & \multicolumn{2}{c}{ Soil layers } \\
\cline { 2 - 3 } Not compressed & $0-10 \mathrm{~cm}$ & $10-20 \mathrm{~cm}$ \\
$\begin{array}{l}\text { Compressed with Cambridge } \\
\text { roller before sowing }\end{array}$ & 19.3 & 21.8 \\
$\begin{array}{l}\text { Compressed with spur roller } \\
\text { before sowing }\end{array}$ & 19.7 & 20.0 \\
$\begin{array}{l}\text { Compressed with Cambridge } \\
\text { roller after sowing }\end{array}$ & 19.4 & 23.6 \\
$\begin{array}{l}\text { Compressed with spur roller after } \\
\text { sowing }\end{array}$ & 18.9 & 21.7 \\
\hline
\end{tabular}

$\mathrm{P}>0.05$.

Table 8. The influence of soil compressing methods and time on sugar beet seedbed moisture content, 2004-2005, 2007.

\begin{tabular}{|c|c|c|c|}
\hline \multirow{2}{*}{$\begin{array}{l}\text { Soil compressing method } \\
\text { and time }\end{array}$} & \multicolumn{3}{|c|}{ Sugar beet seedbed layers } \\
\hline & $0-1.5 \mathrm{~cm}$ & $1.5-3.0 \mathrm{~cm}$ & $3.0-4.5 \mathrm{~cm}$ \\
\hline Not compressed & 4.2 & 10.1 & 16.4 \\
\hline $\begin{array}{l}\text { Compressed with Cambridge } \\
\text { roller before sowing }\end{array}$ & 4.6 & 7.6 & 13.6 \\
\hline $\begin{array}{l}\text { Compressed with spur roller } \\
\text { before sowing }\end{array}$ & 4.1 & 7.8 & 15.6 \\
\hline $\begin{array}{l}\text { Compressed with Cambridge } \\
\text { roller after sowing }\end{array}$ & 6.2 & 10.2 & 14.1 \\
\hline $\begin{array}{l}\text { Compressed with spur roller } \\
\text { after sowing }\end{array}$ & 4.0 & 9.4 & $13.1^{*}$ \\
\hline
\end{tabular}

compressing with spur roller after sowing had negative significant impact on moisture content of deeper seedbed layer.

\section{Conclusions}

Reduction of primary soil tillage intensity from annual deep ploughing to shallow ploughing, deep and shallow cultivation and no tillage conserve soil water. The highest storage of soil water in spring was observed in non-reversibly tilled or not tilled soil.

Subsoiling led to higher water infiltration rate, and top layer of subsoiled soil consisted less moisture content than ploughed.

Sugar beet seedbed moisture mostly depended on soil tillage intensity and depth. Pre-sowing rotary tilling is the top tillage method in the case of water preservation for ploughed or unploughed soil.

Soil compressing with rollers mostly had negative or low influence on light loam luvisol moisture content. Rolling with Cambridge roller effected on more rapid water transport from deeper to top sugar beet seedbed layers and higher evaporation rate.

\section{Acknowledgements}

Paper presents research findings, which have been obtained through postdoctoral fellowship (No. 004/38). It was being funded by the European Union Structural Funds project "Postdoctoral Fellowship Implementation in Lithuania".

We also would like to thank Mrs. Vilma Pilipavičienè for help in English paper correction.

\section{REFERENCES}

[1] J. He, H. W. Li, X. Y. Wang, A. D. McHugh, W. Y. Li, H. W. Gao and N. J. Kuhn "The Adoption of Annual Subsoiling as Conservation Tillage in Dryland Maize and Wheat Cultivation in Northern China," Soil and Tillage Research, Vol. 94, No. 2, 2007, pp. 493-502. doi:10.1016/j.still.2006.10.005

[2] I. G. Martínez, C. Ovalle1, A. Del Pozo, H. Uribe, N. V. Valderrama, Ch. Prat, M. Sandoval, F. Fernández and E. Zagal, "Influence of Conservation Tillage and Soil Water Content on Crop Yield in Dryland Compacted Alfisol of Central Chile," Chilean Journal of Agricultural Research, Vol. 71, No. 4, 2011, pp. 615-622. doi: $10.4067 / \mathrm{S} 0718-58392011000400018$

[3] J. Flexas, J. Bota, J. Galmés, H. Medrano and M. RibasCarbó, "Keeping a Positive Carbon Balance under Adverse Conditions: Responses of Photosynthesis and Respiration to Water Stress," Physiologia Plantarum, Vol. 127, No. 3, 2006, pp. 343-352. doi:10.1111/j.1399-3054.2006.00621.x

[4] P. D. R. Herden, J. W. Swanepoel and G. H. J. Kruger, "Modulation of Photosynthesis by Drought in Two Desert Scrub Species Exhibiting $\mathrm{C}_{3}$-Mode $\mathrm{CO}_{2}$ Assimilation," Environmental and Experimental Botany, Vol. 61, No. 2, 2007, pp. 124-136. doi:10.1016/j.envexpbot.2007.05.005

[5] N. Nakayama, H. Saneoka and R. E. A. Moghaieb, "Response of Growth, Photosynthetic Gas Exchange, Translocation of ${ }^{13} \mathrm{C}$-Labelled Photosynthetic and Accumulation in Two Soybean (Glycine max L. Merrill) Cultivars to Drought Stress," International Journal of Agriculture and Biology, Vol. 9, No. 5, 2007, pp. 669-674

[6] E. Sarauskis, F. Godlinski, A. Sakalauskas, M. Schlegel, N. Kanswohl, K. Romaneckas, A. Jasinskas and V. Pilipavicius, "Effects of Soil Tillage and Sowing Systems on Sugarbeet Production under the Climatic Conditions of Lithuania," Landbauforschung, Vol. 60, No. 2, 2010, pp.101-110.

[7] M. A. Licht and M. Al-Kaisi, "Strip-Tillage Effect on Seedbed Soil Temperature and Other Soil Physical Properties," Soil and Tillage Research, Vol. 80, No. 1-2, 2005, pp. 233-249. doi:10.1016/j.still.2004.03.017

[8] D. Feizienè, V. Feiza and G. Kadžienè, "The Influence of Meteorological Conditions on Soil Water Vapour Exchange Rate and $\mathrm{CO}_{2}$ Emission under Different Tillage Systems," Zemdirbyste = Agriculture, Vol. 96, No. 2, 2009, pp. 3-22. 
[9] D. Simanskaite, "The Effect of Ploughing and Ploughless Soil Tillage on Soil Physical Properties and Crop Productivity," Žemès ükio Mokslai-Agricultural Sciences, Vol. 14, No. 1, 2007. pp. 9-19.

[10] A. W. Lenssen, G. D. Johnson and G. R. Carlson, "Cropping Sequence and Tillage System Influences Annual Crop Production and Water Use in Semiarid Montana" Field Crops Research, Vol. 100, No. 1, 2007, pp. 32-43. doi:10.1016/j.fcr.2006.05.004

[11] E. Sarauskis, K. Romaneckas and S. Buragiene, "Impact of Conventional and Sustainable Soil Tillage and Sowing Technologies on Physical-Mechanical Soil Properties," Environmental Research, Engineering and Management, Vol. 3, No. 49, 2009, pp. 36-43.

[12] V. Feiza, D. Feiziene, G. Kadziene, S. Lazauskas, I. Deveikyte, A. Slepetiene and V. Seibutis, "Soil State in the 11th Year of Three Tillage Systems Application on a Cambisol," Journal of Food, Agriculture \& Environment. Vol. 9, No. 3-4, 2011, pp. 1088-1095.

[13] P. I. Moraru and T. Rusu, "Effect of Tillage Systems on Soil Moisture, Soil Temperature, Soil Respiration and Production of Wheat, Maize and Soybean Crops," Journal of Food, Agriculture \& Environment, Vol. 10, No. 2, 2012, pp. 445-448.

[14] V. Pilipavicius, R. Romaneckiene and K. Romaneckas, "Crop Stand Density Enhances Competitive Ability of Spring Barley (Hordeum vulgare L.)," Acta Agriculture Scandinavica. Section B: Soil and Plant Science, Vol. 61, No. 7, 2011, pp. 648-660.

[15] IUSS Working Group World Reference Base, "World Reference Base for Soil Resources," 2nd Edition, World Soil Resources Reports No. 103, FAO, Rome, 2006, pp. 86-87.

[16] D. Hillel, "Introduction to Soil Physics," Academic Press, Inc., Harcourt Brace Jovanovich Publishers, San Diego, 1982, pp. 58-63.

[17] G. Kritz, "Physical Conditions in Cereals Seedbeds. A Sampling Investigation in Swedish Spring-Sown Fields," Reports of the Division of Soil Management, Uppsala, 1983.

[18] I. Håkansson, Å. Myrbeck and A. Etana, "A Review of Research on Seedbed Preparation for Small Grains in
Sweden," Soil and Tillage Research, Vol. 64, No. 1-2, 2002, pp. 23-40. doi:10.1016/S0167-1987(01)00255-0

[19] K. J. Rasmussen, "Impact of Ploughless Soil Tillage on Yield and Soil Quality: A Scandinavian Review," Soil \& Tillage Research, Vol. 53, No. 1, 1999, pp. 3-14. doi:10.1016/S0167-1987(99)00072-0

[20] D. J. Lyon, W. W. Stroup and R. E. Brown, "Crop production And Soil Water Storage in Long-Term Winter Wheat-Fallow Tillage Experiment," Soil \& Tillage Research. Vol. 49, No. 1-2, 1998, pp. 19-27. doi:10.1016/S0167-1987(98)00151-2

[21] K. P. Fabrizzi, F. O. Garcia, J. L. Costa and L. I. Picone, "Soil Water Dynamics, Physical Properties and Corn and Wheat Responses to Minimum and No-Till Systems in the Southern Pampas of Argentina," Soil \& Tillage Research, Vol. 81, No. 1, 2005, pp. 57-69. doi:10.1016/j.still.2004.05.001

[22] R. Q. Cannel and J. D. Hawes, "Trends in Tillage Practices in Relation to Sustainable Crop Production with Special Reference to Temperate Climates," Soil and Tillage Research, Vol. 30, No. 2-4, 1994, pp. 245-282. doi:10.1016/0167-1987(94)90007-8

[23] H. Tsuji, H. Yamamoto, K. Matsuo and K. Usuki, "The Effect of Long-Term Conservation Tillage, Crop Residues and P Fertilizers on Soil Conditions and Responses of Summer and Winter Crops on Andosol in Japan," Soil and Tillage Research, Vol. 89, No. 2, 2006, pp. 167-176. doi:10.1016/j.still.2005.07.005

[24] G. P. Lafond, W. E. May, F. C. Stevenson and D. A. Derksen, "Effects of Tillage Systems and Rotations on Crop Production for a Thin Black Chernozem in the Canadian Prairies," Soil and Tillage Research, Vol. 89, No. 2, 2006, pp. 232-245. doi:10.1016/j.still.2005.07.014

[25] K. Romaneckas, R. Romaneckienè, V. Pilipavičius and E. Šarauskis, "Effect of Sowing Depth and Seedbed Rolling on Sugar Beet," Zemdirbyste-Agriculture, Vol. 96, No. 1, 2009, pp. 39-52.

[26] K. Romaneckas, R. Žulienè and R. Romaneckienè, “The Influence of Different Presowing Tillage Methods on Agrophysical Soil Properties and on Sugar Beet Seed Field Germination," Zemdirbyste-Agriculture, Vol. 73, 2001, pp. 147-158 (in Lithuanian with English Summary). 